\title{
Open Space Worship: A Religious Identity of the Johane Masowe Chishanu Church in Zimbabwe
}

\author{
Phillip Musoni \\ emusonp@unisa.ac.za \\ Paul H. Gundani \\ gundanip@zou.ac.zw
}

\section{Abstract}

This study examines 'open space' worship that has typified the religious identity of the Johane Masowe Chishanu Church ('John of the wilderness' Church that congregates on Fridays) in Zimbabwe. The Johane Masowe Chishanu Church (JMCC) is a Zimbabwean African indigenous church with branches in many countries. These congregations, being in Zimbabwe and other countries, are recognizable by their white garments and gatherings in open spaces for church services. The practice of congregating in open spaces has been condemned by city fathers, town planners, and government authorities guided by health policies and by-laws (Lubinda 2015; Ncube 2016). In spite of these condemnations, the JMCC has continued to use available open spaces for its services. Our understanding is that congregating in open spaces has become an integral part of the JMCC's history and theological identity. In this article, we examine the veracity and provenance of this assumed identity by interrogating the church's traditions, its relations with colonial authorities, and its theology of open spaces. Borrowing from the theory on identity formation (Dominelli 2002), our contention is that a combination of factors contributes to the JMCC's continued practice of gathering for worship in open spaces. These factors include the sectarian influences on the JMCC, the African spiritual ethos within which it was founded, as well as the colonial 'othering' and subsequent marginalization. 
Keywords: Johane Masowe Chishanu Church (JMCC), African indigenous churches (AICs), colonial government, identity formation, 'othering', open spaces, sect, pseudo-religious movements

\section{Introduction}

The Johane Masowe Chishanu Church (JMCC) is known for congregating and worshiping in open spaces known to its members as the masowe (Mukonyora 2000). City fathers, town planners, government health officials, and the courts have criticized this practice as a nuisance and a threat to the citizenry (Ncube 2016). Accordingly, in this study we discuss factors that influenced the practice of gathering in open spaces for worship - a practice which has become associated with the church's identity in Zimbabwe and abroad. In this qualitative desktop study, we argue that the practice has become an integral component of the church's theology and spirituality. The study is divided into three broad sections: The first section discusses the calling of Shonhiwa Masedza who later became known as Johane Masowe and the influences behind the formation of his church; the second section deals with the attitude of the colonial government towards Masowe and his church; and the third and final section deals with Masowe's understanding of his call and his quest for an African theological identity. These three sections, knitted together, outline the extent to which this Zimbabwean church has identified its church theology with open space congregations, both in- and outside Zimbabwe.

\section{The Life and Calling of Shonhiwa Masedza}

The history of the founder of the Johane Masowe Chishanu religious movement is characterized by mystery and secrecy. Though the founder is regarded as one of the most renowned religious figures in Zimbabwe, very little of his life is known. Prior to his calling to the prophetic ministry, he grew up under the family name of Shonhiwa Masedza from Tanda, Gandanzara in Rusape (Mukonyora 2007:11). According to one tradition, Masedza left for Norton in 1932 where he worked as a cobbler (Hallencreutz 1998:27). Later, he changed his name to Johane Masowe while praying at Marimba hill just outside Norton. Historical evidence points to an earlier flirting with the 
burgeoning Apostolic Faith Mission (AFM) in the Zvimba district and Norton. According to Hallencreutz (1998:193), Shonhiwa was baptized by 'Kachembere', one of the most celebrated African agents of the gospel in the Zvimba-Norton area. Apparently, he left the AFM to form his own religious movement. According to Mukonyora (2007:11), he adopted the name 'Johane', implying that his calling was similar to that of John the Baptist. Like John the Baptist who carried out his mission in the wilderness near the Jordan River, Shonhiwa became Johane Masowe (John of the wilderness). He also derived his ritual behavior from the mission of John the Baptist (Mukonyora 2007:12). His vision was to establish an African church for black Africans only (Musoni 2019). In pursuit of his vision of establishing a black African church, which is different from white missionary churches, he breached colonial norms by calling people out to pray at open spaces (sowe in the Chimanyika dialect of the Shona language) - places that government authorities wished to keep open for landscaping or future planning (Mukonyora 2007:2012). Foreign as the practice was to colonial authorities and administrators, Masowe managed to raise congregations in both town and country.

Right from the early days of the Johane Masowe Church, its founder and leader was a marked man. It is against this background that the then Rhodesian government authorities decided to monitor and restrict Masowe's movements. By the end of October 1932, the Chief Native Commissioner (CNC) in Salisbury was informed that an African prophet - calling himself 'John the Baptist' - was preaching in open spaces in the Norton district of central Mashonaland (Dillon-Malone 1978:11). Masowe was reprimanded and told not to preach again in the town. He responded by moving out of town to rural areas. In 1933, he proceeded to the Nyamweda in the Mhondoro Tribal Trust Lands (Hallencreutz 1998:191).

According to an oral church tradition, on one Friday night, Masowe decided to attend a traditional ceremony (Musoni 2017:15). In line with the traditional customs of the Nyamweda people, Friday was a sacred day dedicated to the veneration of their ancestors (chisi). Hence, no one was allowed to work in the fields on the chisi day. As was the norm, community members were expected to spend the whole Friday night (pungwe) in an open space, venerating the mhondoro (i.e. lion spirits) of the Nyamweda ruling class. The whole Nyamweda village would converge at the chief's court for the dancefilled night. At the pungwe, Masowe stood up and started preaching repen- 
tance (Musoni 2017:11). According to this church tradition, many people were convicted by his teaching. On Saturday morning, he instructed those who had believed in his message of repentance to follow him into the wilderness (sowe) for more rituals. On arriving at a muhacha tree, Masowe fell asleep like a dead person. After an hour or so, he woke up and requested a clay pot (mbiya) to use for his religious rituals. When provided with a pot, he put three small stones in it and started singing, 'Hosanna! Hosanna!' (Musoni 2017:76). The Nyamweda event marked the beginning of Masowe's rural mission. For a long time, he was forced by the colonial state to remain in peri-urban areas (Werbner 1989:320).

This study opines that the identity of the leader of this religious movement was shrouded in secrecy and mystery. This is because of several fictitious names that Masowe used from time to time. It is curious to note that he had several other names that he was known by in different places. While the residents of Norton knew him as 'Sixpence' (Mukonyora 2007:28) obviously an appropriate nickname for a cobbler based on the average fee he charged for his services - in Salisbury, the police knew him as Takawira or Mtunyane (Dillon-Malone 1978:12). In both Ramakgabane (in Botswana) and Korsten (in Port Elizabeth), where he temporarily settled with some of his followers, Masedza was known as Jack Sithole (Hallencreutz 1998:195). In light of the name changes, it is not surprising that Bengt Sundkler refers to Masowe as the 'secret Messiah' (cf. Dillon-Malone 1978:30). While working on his seminal study of African Independent Churches (AICs) in Southern Africa, Sundkler made several attempts to interview Masowe at Korsten. He was disappointed to learn that he could not meet the church founder, but instead was led to meet a certain Jack Sithole. Little did he know that the socalled Jack Sithole was the actual Johane Masowe that he was looking for (Hallencreutz 1998:188). This raises questions on the secretive nature of the life and calling of this African religious leader. It is against this background that Sixpence Mtunyadze Masedza changed his name to 'John of the open spaces' (Johane Masowe) which later became the church's name and identity.

Controversial as he was, it is apparent that Masowe continued to change his name to the outside world because the colonial authorities were on his trail, wishing to arrest him. The colonial authorities were always on his trail for two main reasons: First, he was accused of occupying undesignated land for church services in contravention of the Land Apportionment Act (1931) (Mukonyora 2007:46), and second, he was accused of contravening 
the Witchcraft Suppression Act (1899) (Dillon-Malone 1978:90). While the Witchcraft Suppression Act was promulgated to protect victims of witchcraft accusations from the community's wrath, in his ministry, Masowe continued to acknowledge the existence of varoyi (i.e. witches) and consistently preached against witchcraft. He also appealed to his captive audience to confess and repent from acts associated with witchcraft (Sundkler \& Steed 2000:55). This practice put his converts at risk among traditional African communities. He was consequently arrested several times because of his teaching that witchcraft was not an illusion but a reality among the Shona peoples of Zimbabwe.

With the foregoing in mind, it is understandable why Masowe's church was not recognized by the colonial government. In addition, the utilization of open spaces became a survival strategy for him as it provided an easy escape route from the colonial police. His members also had an easy opportunity to disperse if the police intended to arrest them. Unwittingly, congregations in open spaces for worship became a form of protest against the colonial subjugation, displacement, and marginalization for Masowe and his church. It is little wonder that Masowe became a celebrated hero in the difficult and inhibiting political environment of the 1930s and 1940s (Mukonyora 2000:9). In those days, congregating for worship at open spaces was like a peaceful demonstration against the settler colonialists who had robbed Africans of their land. Since then, branches of the JMCC are found on the fringes of societies in dry, poor areas where there is no production (Mukonyora 2000:13). Invariably, most of these places of worship are located near rivers, crossroads, and hills. Colonial restriction and confinement to rural areas may indeed have brought Masowe and his followers to the realization that their church was indeed a church of the wilderness (masowe), as opposed to churches of white missionaries that worshiped in church buildings.

\section{Johane Masowe Church as a 'Sect' and/or 'Pseudo-religious Movement'}

According to Dominelli (2002:38), 'oppressive relationships encompass identity formation through power relations that draw on the categorisation of the world in dichotomous terms, whereby one person or group of people is 
defined as superior or dominant and the other(s) as inferior or subordinate according to the values ascribed to particular attributes and social positions'. Hence, if an individual or group does not have the characteristics specified as desirable, they become socially excluded and subjected to marginalization. In the following section, we investigate the dominant power dynamics in colonial Rhodesia vis-à-vis charismatic religious movements, in particular the AFM and the JMCC. Our analysis is influenced by Dominelli's approach to identity formation.

The restriction of Masowe was not an isolated case in the history and development of African initiated churches (AICs) in colonial Zimbabwe. Generally, colonial authorities in Rhodesia denied the recognition of charismatic/spirit-type church movements and labelled them as 'pseudo-religious movements' or 'sects' (Dillon-Malone 1978:19). The AFM was the first charismatic/spirit-type church to be denied church status in colonial Rhodesia (Ruzivo 2014:80). The AFM first operated in the villages of Gwanda in 1915, under the leadership of Reverend Zacharias Malamela from the Transvaal (Hwata 2005:36). Although the AFM in Rhodesia operated under the oversight of white South African leaders, Rhodesian authorities did not recognize it as an orthodox church, the main reason being the phenomena of glossolalia and the ecstatic outpouring associated with its members. Colonial authorities in Rhodesia saw in these practices reminiscences of African spiritism that reminded them of the Ndebele and Shona uprisings (18961897) - hence the label 'pseudo-religious movement'. It is no wonder, therefore, that in 1919, a report by the CNC of the Gwanda District expressed strong disapproval of the AFM as a Christian church. The CNC wrote:

I do not know what particular fray branch of religion this is but it appears to be of the rollers, tumblers, and groaners etc, as I am informed that when the teacher is worked up he rolls on the ground, throws himself about, groans, screams, shouts, and makes noises like a lion...a beast and various other noises. I am not in favour of a branch of this religion. I am certainly not in favour of a branch of this religion, wherever it is being established in this district. In my opinion the procedure and fancy ideas will do more harm than good, and we may have a number of maniacs on our hands (Ruzivo 2014: 94). 
The above description of the AFM specifically shows resonance with African spirit possession. Thus, according to the CNC, making a noise like a lion resonated too closely with the Shona mhondoro cult that we have referred to above.

It is against this background that the colonial government refused to recognize JMCC which appeared on the Zimbabwean religious scene in 1932, some many years after the AFM was denied its status as a Christian church. It is reasonable to explain the refusal by the colonial government in Rhodesia to recognize Masowe's church considering the fact that his movement had roots in the AFM (Hallencreutz 1998:193). The former shared the same ecstatic features with the latter.

Another common colonial description of the charismatic/spirit-type churches was the term 'sect'. The CNC of Gwanda, cited above, used the term 'sect' to describe the AFM. His argument went as follows: 'Faithhealing and emotionalism are prominent features of this sect. The psychic and moral effect of such teaching, to my mind, must tend to foster delusions among the native community...Emissaries of such sects are a menace to the administration by stirring up discontent among the natives' (Dillon-Malone 1978:9).

In using the term 'sect', the CNC pointed to the potential threat to peace and order associated with such movements, considering that 'sects' generally appeal principally to the lower classes or the 'riffraff' (Johnson 1963:540). To colonial authorities, 'sects' were considered dangerous because of their potential to disturb peace in the colony, especially because of their tendency to negate the existing social order. A millennial streak in Masowe goes to explain why the colonial government refused to recognize his movement and restricted him.

Spirit-type churches are sometimes referred to as millenarian movements (Bishau 2010) because of their theology of apocalypticism, emphasizing an imminent Parousia (Hallencreutz 1998:188). Millenarian movements emphasizing an imminent Parousia, taught that the governments of the day were part of an evil system controlled by the devil. Accordingly, they prohibited their members from working in government departments and shunned political participation (Bishau 2010). Such movements and Christian sects also eschewed seeking recourse from the legal and judicial systems. There is ample evidence, however, to suggest that the theology and spirituality of the JMCC resonated with Sabbatarianism and the beliefs of the 
Jehovah's Witnesses (Hallencreutz 1998:192). Typically, Masowe preached to the members of his church not to seek formal employment and not to work for the governments of this world - they should rather serve and belong to the heavenly Kingdom. Masowe's popular refrain was that 'Israelites cannot work for non-Israelites', and in this way he implied that members of his church were the Israelites while the colonial government and white employers were non-Israelites (Werbner 1989:132). Instead of working for the government or private sector run by white men, Masowe taught his members to use their own hands, therefore to be self-employed. Hence, basketmaking became the church's flagship. In the context of the JMCC's world negating theology, one can understand why, during the years that Masowe spent at Korsten, the Salisbury Daily News, dated June 6, 1962, reported that the basketmakers were constantly building an ark which they believed was going to carry them to the New Jerusalem. Like Noah, Masowe was leading and preparing his members towards an imminent worldly Eschaton, characterized by great destruction (Dillon-Malone 1978:214).

Masowe's teaching on the dignity of self-reliance and the theology of an imminent eschatology had serious tax implications for the colonial government in light of the fact that all the Masowe members opted out of the government's revenue collection system. Furthermore, the use of open spaces for worship was meant to send a clear message to its members that there was no need to build structures. Thus, the JMCC also subverted and bypassed land tax associated with ownership and/or the rental of land. Such teachings and beliefs provided an added reason why this article argues that this Zimbabwean church has adopted open space worship as its religious identity inside Zimbabwe, as well as outside the Zimbabwean borders.

\section{Open Space Congregation: A Quest for an African Theological Identity}

The quest for identity is, at its heart, a search for self-understanding. Thus, the question is, How did Johane Masowe understand his call to establish an African indigenous church in an environment of numerous European Christian churches? For John de Gruchy (2014:15), 'identity has to do with images, the way in which we communicate who we are; the way in which the media represent us and therefore the way in which others relate to us'. As 
such, the quest for identity is inseparable from our reason for existence. It is important to underscore the point that congregating for worship in the wilderness was not due to a lack of resources to build church buildings (Mukonyora 2000), but rather a deliberate decision borne out of deliberate ideological and theological preferences that were located in a specific political, cultural, and economic context. This view is supported by the fact that, at one stage, a white missionary offered to build a church for Masowe, which the latter refused to take (Dillon-Malone 1978:58).

Furthermore, congregating for worship at open spaces seems to have been predicated on, and motivated by, a conscious reappropriation of the preChristian African approach to God. Mbiti (1975) notes that congregating at open spaces was an African way of celebrating and connecting with the divine. For him, Africans had already developed ways of approaching their God through certain sacred places long before missionaries came to Africa. These sacred places included open spaces under certain trees and near certain pools and rivers (Mbiti 1975:23). Thus, prior to the arrival of Islam and Christianity - the two dominant religions in contemporary Africa - Africans believed that nature is a privileged locus for encountering the gods, goddesses, deities, and ancestral spirits (Mbiti 1980:817). Accordingly, many African indigenous churches hold their prayers and worship services on mountain tops, hills, caves, beaches, and clearings in the forest (Orobator 2008:146). The Shona people, for instance, used to venerate their ancestors under the muhacha tree in open spaces. The launching of Masowe's evangelism under a muhacha tree and the using of clay pots reflect the influence of a Shona traditional religious spirituality, a spiritual context from which he was brought up. In Shona spirituality, the muhacha tree and clay pots are associated with ritual significance and symbolism (Bourdillon 1987).

Similarly, when we compare Masowe's religious experiences to African pre-Christian religious practices, we get an insight into the way in which the structure and spirituality of his church movement was formed. In line with his quest for an African identity, Masowe preached that black Africans must return and adopt their pre-Christian religious practices - the practices of their forefathers - and they should burn the religious books of the Europeans and shun their temples because their forefathers did not have books and temples for worship (Dillon-Malone 1978:17). Masowe was very clear in spelling out his mission to black Africans. For him, the white man's world, from which they had been excluded, was evil and would be over- 
thrown (Dillon-Malone 1978:17). Thus, for Masowe's religious movement, the coming of the Kingdom of Heaven meant that God was going to intervene to restore the goods and material resources which had been taken from the black man. White missionary Christianity was condemned for failing to bring saving power to the black man. Hence, it was to be shunned and rebranded as African Christianity that addressed Africans and their existential problems. In this study, we term this theological discourse a 'theology of subversion'. We see the first fruits of this theological paradigm in 1907 when Matthew Zvimba, who was a Methodist catechist, was expelled from the Wesleyan Methodist Church, accused of a series of clashes with the white missionary administrators (Ranger 1970:20). After his expulsion, Zvimba founded the first African indigenous church called the Shiri Chena ('white bird') Church (Ranger 1970:21). This church was indeed very explicitly a Shona church. The white bird of its title was not only the dove of the holy Spirit but also the traditional messenger of the high god Mwari to mankind (Ranger 1970:21). Accordingly, Zvimba drew up lists of those who had been killed in the 18961897 fighting in Zvimba and these were regarded as the saints and martyrs of the Shiri Chena Church (Ranger 1970:21). The Christian solution for Zvimba was now to be carried out in defiance of the whites. The Shiri Chena Church effectively illustrates how ostensibly fringe Christian imagery, metaphor, and myth could be mobilized and utilized not only to express tribal grievance (Ranger 1970), but also to enhance African pride and to empower disenfranchised Africans.

The theological resonance between the JMCC and Zvimba's Shiri Chena Church poignantly illustrates the African disdain to an alienating and iconoclastic Constantinian-based Christian theology associated with Western missionaries who looked down on African cultures and practices. Clearly, the founders of these two African indigenous churches questioned the fundamental rationale of Euro-American missionaries in Africa. Although their mission appeared to be based on 'an attitude of goodwill', they ultimately had a hidden agenda of dislocating African societies by replacing African traditional culture with the so-called favorable Christian (Western culture) and civilization (Amanze 1998:52). According to Amanze (1998:52), becoming a Christian in Africa was only possible if Africans renounced their African past - their beliefs and practices - and were expected to show a willingness to live according to Western norms. Although Masowe did not advocate for the return to African beliefs and practices such as the killing of twins, ancestor 
veneration, and witchcraft, he was not amused by the contempt expressed by colonial settlers and missionaries over African cultures, African sacred shrines, and the African sense of self-worth.

\section{Conclusion}

The foregoing discussion is an illustration of the evolution of identity formation in the JMCC. Since 1932, when Shonhiwa Masedza was called to the prophetic ministry, congregating for worship on open spaces has become his church's trademark. Open air congregations on available open spaces have become an integral part of the church's identity. Clearly, the brand of Masowe's theology and ecclesiology was borne out of the politicization of difference by colonial authorities in Rhodesia. The politicization of difference created symbolic representations which privileged the attributes of mission Christianity at the expense of the churches that colonial authorities labelled as 'sects' or 'pseudo-religious movements'. By such categories, colonial authorities in Rhodesia, advised by Western missionaries, created new identities of churches and set up borders and boundaries between Christian groups. In spite of the oppressive and disempowering political and cultural milieu in which the JMCC was formed and evolved, Masowe managed to forge a brand of Christianity that was not only anti-colonial but authentically African. Although the practice of congregating in open spaces has been condemned by city fathers, town planners, and government authorities, guided by health policies and by-laws, the JMCC continues to utilize available open spaces for its services and insist that assembling in such spaces is an integral part of its history and identity. In protecting its Christian identity, the JMCC continues to subvert post-colonial administrative and regulatory regimes of governance.

\section{References}

Amanze, J. 1998. African Christianity in Botswana. $1^{\text {st }}$ ed. Gweru: Mambo Press.

Bishau, D. 2010. Reign with him for thousand years (Rev 20:6): A sociohermeneutical expositition of biblical and contemporary millenarian movements in Zimbabwe as radical responses to deprivation. In Kugler, J., L. Togarasei \& M. Gunda (eds.): Études sur la Bible en 
Afrique Bibel-in-Afrika-studien. Vol. 2. Bamberg: University of Bamberg Press.

Bourdillon, M. 1987. The Shona peoples: An ethnography of the contemporary Shona, with special reference to their religion. Gweru: Mambo Press.

De Gruchy, J.W. 2014. The quest for identity in so-called mainline churches in South Africa. In Conradie, E.M. \& J. Klaasen (eds.): The quest for identity in so-called 'mainline' churches in South Africa. Stellenbosh: Sun Press.

Dillon-Malone, C. 1978. The Korsten basketmakers: A study of the Masowe apostles, an indigenous African religious movement. Manchester: Manchester University Press.

Dominelli, L. 2002. Anti-oppressive social work theory and practice. Springer Link. Available at: https://doi.org/10.1007/s11266-008-9077-5. (Accessed on 24 September 2019.)

Hallencreutz, C. 1998. Religion and politics in Harare 1890-1980. Uppsala: Swedish Institute of Missionary Research.

Hwata, B. 2005. An investigation of different phases of Pentecostal experience in the Apostolic Faith Mission (AFM) in Zimbabwe. MTh dissertation, Systematic Theology, Unisa, Pretoria. Available at: http://uir.unisa.ac.za/bitstream/handle/10500/1655/dissertation.pdf?seq uence $=1 \&$ isAllowed=y. (Accessed on 24 September 2019.)

Johnson, B. 1963. On church and sect, American sociological review. Available at: https://www.jstor.org/stable/2090070. (Accessed on 22 January 2019.)

Lubinda, L. 2015. Debate over Mapostori use of open spaces. Harare News, 16 June, 10-17. DOI: 10.1145/3132847.3132886. (Accessed on 24 September 2019.)

Mbiti, J.S. 1975. African religions \& philosophy. London: Heinemann.

Mbiti, J. 1980. The encounter of Christian faith and African religion. Christian Century Foundation 27, 3: 817-820.

Mukonyora, I. 2000. Marginality and protest in the sacred wilderness: The role of women in shaping Masowe thought pattern. Southern African Feminist Review 4, 2: 1-21.

Mukonyora, I. 2007. Wandering a gendered wilderness: Suffering and healing in an African initiated church. New York: Peter Lang. 
Musoni, P. 2017. Inculturated African spiritual elements in Johane Msowe weChishanu yeNyenyedzi Church in Zimbabwe. PhD thesis, Church History, University of Pretoria. Pretoria.

DOI: $10.1056 /$ NEJM187303060881006.

Musoni, P. 2019. African indigenous churches for black Africans: A study of the Johani Masowe Chishanu yeNyenyedzi (JMCN) missiological thrust in the diaspora. Studia Historiae Ecclesiasticae 45, 2: 1-16.

Ncube, L. 2016. Council scores victory in open air worship war. Chronicle. Available at: https://www.chronicle.co.zw/council-scores-victory-inopen-air-worship-war/16. (Accessed on 13 February 2019.)

Orobator, A.E. 2008. Theology brewed in an African pot. Maryknoll: Orbis Books.

Ranger, T. 1970. The African voice in Southern Rhodesia 1898-1930. London: Heinemann.

Ruzivo, M. 2014. A history of the Apostolic Faith Mission in Zimbabwe 1908-1980. Pretoria: University of South Africa Press.

Sundkler, B. \& C. Steed 2000. A history of the church in Africa. Cambridge: Cambridge University Press.

Werbner, R.P. 1989. Ritual passage, sacred journey: The process and organization of religious movement. Manchester: Manchester University Press.

Phillip Musoni Post Doctoral Fellow Department of Christian Spirituality, Church History and Missiology emusonp@unisa.ac.za

Paul H. Gundani VC Zimbabwe Open University gundanip@zou.ac.zw 